\title{
Comparative Antibacterial Capabilities of Origanum Onites Oil and Diode Laser against Enterecoccus faecalis Contaminated Primary Root Canals
}

\author{
Aylin İslam ${ }^{1,2} \mathbb{D}$, Serdar Susever ${ }^{2,3}$ (D), Duygu Yiğit Hanoğlu ${ }^{4}$ (D), Kemal Hüsnü Can Başer ${ }^{4}(\mathbb{D}$, \\ Serap Çetiner ${ }^{5}$ (ID) \\ 'Department of Pediatric Dentistry, Near East University Faculty of Dentistry, Northern Nicosia, North Cyprus \\ ${ }^{2}$ Research Center of Experimental Health Sciences, Near East University, Northern Nicosia, North Cyprus \\ ${ }^{3}$ Department of Nutrition and Dietetics, Near East University Faculty of Health Sciences, Northern Nicosia, North Cyprus \\ ${ }^{4}$ Department of Pharmacognosy, Near East University Faculty of Pharmacy, Northern Nicosia, Northern Cyprus \\ ${ }^{5}$ Department of Pediatric Dentistry, Kyrenia University Faculty of Dentistry, Kyrenia, North Cyprus
}

ORCID iDs of the authors: A.I. 0000-000I-6338-4505; S.S. 0000-0002-4988-5634; D.Y.H. 0000-0003-I345-4768; K.H.C.B. 0000-000327I0-023I; S.Ç. 0000-0003-1793-1840.

Cite this article as: İslam A, Susever S, Hanoğlu DY, Başer KHC, Çetiner S. Comparative Antibacterial Capabilities of Origanum Onites Oil and Diode Laser against Enterecoccus faecalis Contaminated Primary Root Canals. Cyprus J Med Sci. 2021; 6(3): $237-243$.

\section{BACKGROUND/AIMS}

Enterecoccus faecalis is the most dominant and most isolated resistant species from infected/failed permanent teeth undergoing root canal therapy or painful primary teeth with periapical radiolucency. The main purpose of the present research was to compare the antimicrobial effectiveness of essential oil of Origanum onites and diode laser irradiation against $E$. faecalis removal from primary root canals.

\section{MATERIAL and METHODS}

A total of 60 retained human primary incisors were selected randomly and divided into six experimental groups as follows: Group I: negative control; Group 2: positive control; Group 3: sodium hypochlorite ( $\mathrm{NaOCl}$ ); Group 4: diode laser; Group 5: Origanum onites (OO) oil; Group 6: diode laser + OO oil. The gas chromatography-mass spectrometry (GC-MS) and GC analyses of OO oil were carried out with an Agilent 5977B GC-MSD and Agilent 7890B GC systems, respectively. A 2-W diode laser was used in a continuous action mode with a wavelength of $980 \mathrm{~nm}$ for 20 seconds. $\mathrm{NaOCl}$ and $\mathrm{OO}$ oil were applied continuously for 5 minutes to each root canal. Multiple comparisons and the significances between experimental groups were statistically analyzed using Tukey's multiple comparisons test. The level of significance was accepted at .05 for the entire statistical analysis $(P=.05)$.

RESULTS

The major reductions were observed in the groups of $\mathrm{NaOCl}(98.3 \%)$ and diode laser + Origanum onites oil combination (92.5\%).

CONCLUSION

Combined therapy of diode laser irradiation following Origanum onites oil application in primary root canal disinfection may be used as an ideal effective chemo-mechanical alternative to $\mathrm{NaOCl}$ irrigation.

Keywords: Origanum onites oil, E. faecalis, diode laser, antibacterial

\section{INTRODUCTION}

The pulpectomy procedure seems to be complicated in primary teeth due to the existence of ramifications, microcanals, and root resorption areas that do not allow sufficient bacterial elimination from the root canal system with mechanical instrumentation and irrigation. ${ }^{1,2}$

Various bacterial species colonize root canals, but Enterecoccus faecalis is the most dominant and most isolated resistant species from infected/failed permanent teeth undergoing root canal therapy or painful primary teeth with periapical radiolucency. ${ }^{3-6}$ The main properties of E. faecalis contribute toward its capacity to adapt to severe environmental 
conditions, as evidenced by its penetration into dentinal tubules, resistance to extreme alkaline $\mathrm{pH}$ values, exhibition of virulence factors, and biofilm formation. ${ }^{7-11}$

Currently, sodium hypochlorite $(\mathrm{NaOCl})$ is still the most used irrigant. However, there are major adverse effects including that it is toxic, functions as an irritant when it reaches the apex because of the physiologic resorption of primary roots, and has harmful effects on dentin elasticity and flexural strength. In addition, it is unsuccessful for smear layer removal with limited dentinal tubule penetration to a depth of $100 \mu \mathrm{m}^{12,13}$

Over the last decade, various alternative irrigative methods consisting of lasers/laser-activated irrigation and ultrasonic/ sonic irrigation systems have been developed and popularized to increase the effectiveness of root canal disinfection and $E$. faecalis elimination. ${ }^{14-16}$

Besides laser technology, the usage of plant-derived/natural/ herbal extracts has increased as new efficient therapies against growing antibacterial resistance and oral bacteria. Various natural extracts or their complexes have been investigated, and it has been shown that herbs can manage oral infections to improve oral health. ${ }^{17}$ Oregano is one of these herbs and is a term which describes different subspecies. The genus Origanum is rich in phenolic compounds with their powerful antibacterial and antifungal capabilities. ${ }^{25}$ Generally, the main components of Oregano essential oils are composed of the monoterpenic phenols carvacrol and thymol. These main components are biosynthesized from $\gamma$-terpinene through $p$-cymene. ${ }^{26,27}$ Oregano essential oils have been reported that exhibit anticarcinogenic, antioxidant, antifungal, antibacterial, antioxidant, analgesic and antispasmodic properties under different growth conditions. ${ }^{28}$

There are limited research investigating some herbal drugs as an intracanal medicament in primary root canals. ${ }^{22-24}$ Various studies have discussed the antibacterial activities and cytotoxicity of Origanum species, particularly, its essential oil on oral microorganisms. ${ }^{|8-2|}$ However, no research has focused on the antibacterial efficiency of specific Origanum onites oil (OO oil) as a root canal irrigant in primary teeth.

In the light of current clinical problems (such as complex morphology of primary teeth, toxic and irritant effects of $\mathrm{NaOCl}$ ), the main objective of the present research was to compare the antimicrobial effectiveness of essential oil of Origanum onites and diode laser irradiation in primary root canals and to sug-

\section{Main Points}

- Combined therapy of diode laser irradiation following O oil application in primary root canal disinfection should be recommended as an ideal effective chemomechanical alternative to $\mathrm{NaOCl}$ irrigation.

- A small difference between the $E$. faecalis reduction percentages of $\mathrm{NaOCl}$ (98.3\%) and diode laser-Origanum onites oil combination (92.5\%) groups was observed.

- Further in vivo investigations with larger sample sizes are required to provide a clinically valuable antibacterial treatment with minimal chair-time as an important point of children s treatment. gest a more conservative clinical alternative to $\mathrm{NaOCl}$ irrigation against $E$. faecalis removal from primary root canals.

\section{MATERIAL and METHODS}

The present experimental study was evaluated and approved by the Institutional Review Board of Near East University (NEU / 2018 / 58-609). The commercial essential oil of Origanum onites was acquired from TûRER Inc.

The commercial essential oil of Origanum onites was acquired from TÜRER Inc.

\section{Gas Chromatography (GC) and Gas Chromatography-Mass Spectrometry (GC-MS) Analysis}

GC-MS Analysis: The GC-MS analysis was carried out with an Agilent 5977B GC-MSD system. Innowax FSC column (60 m $\times$ $0.25 \mathrm{~mm}, 0.25 \mu \mathrm{m}$ film thickness) was used with helium as the car-

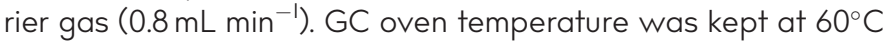
for 10 minutes and programed to $220^{\circ} \mathrm{C}$ at a rate of $4^{\circ} \mathrm{C} \mathrm{min}{ }^{-1}$, and kept constant at $220^{\circ} \mathrm{C}$ for 10 minutes and then programed to $240^{\circ} \mathrm{C}$ at a rate of ${ }^{\circ} \mathrm{C} \mathrm{min}^{-1}$. The split ratio was adjusted to $40: \mathrm{I}$. The injector temperature was set at $250^{\circ} \mathrm{C}$. Mass spectra were recorded at $70 \mathrm{eV}$. Mass range was from $\mathrm{m} / \mathrm{z} 35$ to 450 . The sample was dissolved in $10 \% n$-hexane, and I $\mu \mathrm{L}$ was injected.

GC Analysis: The GC analysis was carried out using an Agilent 7890B GC system. The flame ionization detector (FID) detector temperature was $300^{\circ} \mathrm{C}$. To obtain the same elution order with GC-MS, simultaneous auto-injection was done on a triplicate of the same column applying the same operational conditions. Relative percentage amounts of the separated compounds were calculated from FID chromatograms.

Identification of Compounds: Identification of the essential oil components was carried out by comparison of their relative retention times with those of authentic samples or by comparison of their linear retention index (LRI) to series of $n$-alkanes. Computer matching against commercial databases (Wiley GC/MS Library, NIST Chemistry Volatile oil constituents of Origanum species WebBook) 29,30 and in-house "Başer Library of Essential Oil Constituents" built up by genuine compounds and components of known oils, as well as MS literature data were used for the identification. 31,32

Antimicrobial Susceptibility of Origanum Onites: E. faecalis was incubated at $37^{\circ} \mathrm{C}$ for 48 hours in blood agar (LAB028, LAB M Limited, Lancashire, United Kingdom). The microdilution method was used for the antimicrobial susceptibility test. Extracts were prepared at the following concentrations: 500, $250,125,62.5,32,16,8,4,2,1,0.5,0.25,0.125,0.06$, and $0.03 \mu \mathrm{g} \mathrm{mL}^{-1}$. The bacterial and $E$. faecalis suspensions were adjusted to 0.5 McFarland standard turbidity. In this method, dimethyl sulfoxide (DMSO) (Sigma-Aldrich, Saint Louis, USA) and water were used as control groups. To each of the dilutions, $100-\mu \mathrm{L}$ of broth cultures and $100-\mu \mathrm{L}$ of standard microorganisms were added. The microplates were incubated at $37^{\circ} \mathrm{C}$ for 48 hours. The turbidity reading was performed by a spectrophotometer.

Preparation of Teeth: A total of 60 retained human primary incisors without physiological or pathological resorption on more than one-third of the apical root were used. First, all superficial debris, tissue tags and calculus were removed, and all 
samples were stored in normal saline solution (VACOLITER, Baxter, Turkey). Then, the crowns of the primary teeth were sectioned from the cement enamel junction and, for standardization, the length of the root canals was set at $8 \mathrm{~mm}$. Later, the pulp tissues were extirpated from the root canals, and canals with an apical size of F3 were prepared using rotary instruments ( $x$ smart, DENTSPLY, York, ABD). During the preparing and shaping procedure, $5.25 \%$ sodium hypochlorite $(\mathrm{NaOCl}$, Chlorax, Cerkamed, Wola, Poland) in sterile saline was used as an irrigant agent. At the end of the preparation process, the smear layer was removed using $17 \%$ Ethylenediaminetetraacetic acid (EDTA) (Endo-Solution, Cerkamed, Wola, Poland), and all samples were irrigated again with sterile saline. Before the experiments, all prepared samples were autoclaved at $121^{\circ} \mathrm{C}$ for 30 minutes.

E. faecalis Contamination of Root Canals: A 30- $\mu \mathrm{L}$ suspension of pure cultured E. faecalis Muller Hinton Broth (LABII4, LAB M Limited, Lancashire, United Kingdom) was used to contaminate each root canal with a sterile insulin syringe. After completing E. faecalis contamination, all samples (except negative control group) were incubated at $37^{\circ} \mathrm{C}$ for 48 hours. Following this incubation period, the samples were treated according to the experimental design.

Determination of Experimental Groups: The samples were selected randomly and divided into six equal experimental groups $(n=10)$ as follows:

Group I: negative control (no contamination with E. faecalis, only normal saline);

Group 2: positive control (ATCC 29212 E. faecalis contamination, only normal saline);

Group 3: $5 \mathrm{~mL}$ 2.5\% NaOCl;

Group 4: diode laser;

Group 5: $5 \mathrm{~mL}$ Origanum onites oil; and

Group 6: diode laser $+5 \mathrm{~mL}$ Origanum onites oil (overnight).

\section{$\mathrm{NaOCl}$ and $\mathrm{OO}$ Oil Were Applied Continuously for 5 Minutes to Each Root Canal}

Diode Laser Irradiation: Diode laser irradiation was performed using a diode laser (MEDENCY, Primo, Vicenza, Italy). A 2-W diode laser was used in a continuous action mode with a wavelength of $980 \mathrm{~nm}$ using a $200 \mu \mathrm{m}$ diameter optical fiber for 20 seconds. Laser irradiation was initiated at the coronal portion of each root canal with helicoidal optical fiber movements down to I-mm short of the apical area.

Intracanal bacterial samples were taken before and after canal disinfection to determine the CFU count.

\section{Statistical Analysis}

Multiple comparisons and the significances between mean values of the experimental groups were statistically analyzed using Tukey's multiple comparisons test. The percentages of reduction in colony counts (\%RCC) were evaluated using the following equation:

CFUS (before treatment) - CFUS (after treatment) $\times 100=$ $\%$ RCC

CFUS (before treatment)

\begin{tabular}{|c|c|c|}
\hline LRI & $\begin{array}{l}\text { Compound } \\
\text { name }\end{array}$ & $\begin{array}{l}\text { Relative percentage } \\
\text { amounts (\%) A }\end{array}$ \\
\hline 1020 & $\alpha$-Pinene & 0.4 \\
\hline 1024 & $\alpha$-Thujene & 1.1 \\
\hline 1072 & Camphene & 0.3 \\
\hline 1119 & $\beta$-Terpinene & 0.1 \\
\hline 1172 & Myrcene & 0.6 \\
\hline 1177 & $\alpha$-Phellandrene & 0.2 \\
\hline 1191 & $\alpha$-Terpinene & 1.3 \\
\hline 1213 & Limonene & 0.2 \\
\hline 1222 & $\beta$-Phellandrene & 0.2 \\
\hline 1260 & $\gamma$-Terpinene & 6.9 \\
\hline 1287 & p-Cymene & 4.1 \\
\hline 1298 & Terpinolene & 0.1 \\
\hline 1457 & |-Octen-3-ol & 0.1 \\
\hline 1478 & trans-Sabinene hydrate & 0.4 \\
\hline 1555 & Linalool & 1.4 \\
\hline 1564 & cis-Sabinene hydrate & 0.2 \\
\hline 1569 & Linalyl acetate & 0.1 \\
\hline 1624 & Terpinene-4-ol & 0.7 \\
\hline 1628 & $\beta$-Caryophyllene & 0.5 \\
\hline 1638 & Aromadendrene & 0.1 \\
\hline 1717 & $\alpha$-Terpineol & 0.2 \\
\hline 1728 & Borneol & 0.4 \\
\hline 1748 & $\beta$-Bisabolene & 1.1 \\
\hline 1770 & Carvone & $\operatorname{tr}$ \\
\hline 1786 & $\delta$-Cadinene & $\operatorname{tr}$ \\
\hline 1793 & $\gamma$-Cadinene & 0.1 \\
\hline 1899 & Carvacryl acetate & 0.1 \\
\hline 2033 & Caryophyllene oxide & 0.1 \\
\hline 2159 & Spathunelol & 0.1 \\
\hline 2205 & T2Cadinol & 0.2 \\
\hline 2210 & Thymol & 0.2 \\
\hline 2243 & Carvacrol & 78.4 \\
\hline & Total & 100.0 \\
\hline \multicolumn{3}{|c|}{$\begin{array}{l}\text { A: essential oil of Origanum onites (TÜRER, Inc.); LRI: linear retention } \\
\text { indices calculated against n-alkanes; \%: calculated from FID data; tr: } \\
\text { trace }(<0.1 \%) \text {. } \\
\text { Abbreviations: LRI, linear retention indices; FID, flame ionization detec- } \\
\text { tor; tr, trace. }\end{array}$} \\
\hline
\end{tabular}

\section{RESULTS}

The analysis results of commercial Origanum onites essential oil composition are given in Table I. The totally analyzed essential oil was represented with 32 components. The major compounds were determined as carvacrol (78.4\%), g-terpinene (6.9\%), and $p$-cymene (4.1\%), respectively.

According to the study results, bacterial growth was observed both before and after treatment in all 10 samples of the positive control group, whereas no bacterial growth was observed in the negative control group. Briefly, all samples treated with the diode laser and Origanum onites oil were positive for bacterial growth both before and after treatment. However, for the sodium hypochlorite $(\mathrm{NaOCl})$ group, no bacterial growth was observed after treatment. After the 48 hours cultivation period, a significant decrease was detected for the combined diode laser and Origanum onites oil group.

The percentages of reduction in E. faecalis colony counts after irrigation procedures are shown in Table 2. The major reductions were observed in the groups of $\mathrm{NaOCl}$ and diode laser$\mathrm{OO}$ oil combination. Moreover, the small difference between 
Table 2. E. faecalis Reduction in Colony Counts of Each Group

$\begin{array}{lcc}\text { Groups } & \mathrm{RCC}(\%) & \mathrm{CFU} \mathrm{mL}^{-1}( \pm \mathrm{SD}) \\ \text { Positive control } & 0 & 3.04 \times 10^{5}\left( \pm 6.7 \times 10^{3}\right) \\ \mathrm{NaOCl} & 98.3 & 5.1 \times 10^{3}\left( \pm 2.7 \times 10^{3}\right) \\ \text { Diode laser } & 32 & 2 \times 10^{5}\left( \pm 4.5 \times 10^{3}\right) \\ \text { Origanum onites oil } & 25.5 & 2.26 \times 10^{5}\left( \pm 1.5 \times 10^{4}\right) \\ \text { Diode laser + Origanum onites oil } & 92.5 & 2.2 \times 10^{4}\left( \pm 6 \times 10^{3}\right)\end{array}$

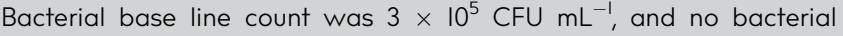
growth was observed in negative control.

Abbreviations: $\mathrm{NaOCl}$, sodium hypochlorite; $\mathrm{RCC}$, reduction in colony counts.

the $E$. faecalis reduction percentages of $\mathrm{NaOCl}(98.3 \%)$ and diode laser-Origanum onites oil combination (92.5\%) groups was found to be statistically significant. A greater reduction was observed in $\mathrm{NaOCl}$ in comparison to the diode laserOriganum onites oil combination $(P=.0317)$. Although Origanum onites oil RCC was about $25.5 \%$ without diode laser irradiation, when Origanum onites oil irrigation was combined with diode laser irradiation, the RCC was detected to be about $92.5 \%$. This difference between groups was found to be significant $(P<.000 \mathrm{l})$. The same trend was detected between diode laser irradiation alone and diode laser-Origanum onites oil combination $(P<.0001)$. The statistical comparisons between all groups are presented in Table 3 .

\section{DISCUSSION}

E. faecalis is isolated with greater frequency from permanent root canals but clinically, it is copiously present in primary root canals. $^{33}$ In endodontic treatments, because of the bactericidal effects of lasers, various kinds of lasers, such as Er:YAG, $\mathrm{Nd}: Y A G$, and diode lasers, have been developed and used to provide infection control. In the present study, the diode laser was preferred because it has a good bactericidal effect and does not cause an unacceptable temperature rise in periodontal/external root tissues. ${ }^{34-36}$ Also, the deep penetration capability of diode lasers into the dentinal tubules has been shown to be satisfactory under in vivo conditions. ${ }^{37}$ For this reason, the diode laser irradiation was performed with a newly designed endodontic tip that was set to operate in the continuous mode for a regular effect at a power output of $2 \mathrm{~W}$. According to Dai et al.'s ${ }^{38}$ study, $2 \mathrm{~W}$ power was used to remove the smear layer on primary teeth while avoiding dentinal melting. However, diode laser irradiation alone with $2 \mathrm{~W}$ power output did not effectively reduce the $E$. faecalis bacterial count (32\%). This ineffectiveness of the diode laser might be explained by biostimulatory effects of laser. The minimal exposure to laser irradiation in the present study may have helped to increase the physiological activities of $E$. faecalis for proliferation instead of reduction. ${ }^{39}$ Also, the wavelength could be another reason that explains inadequate efficiency of diode laser. The wavelength of $980 \mathrm{~nm}$ in diode lasers has a powerful water absorption capacity, so superficial dentin layers benefit from the majority of antimicrobial effects in comparison to deeper tubule layers. ${ }^{40}$ Hence, the disinfection capacity of diode laser is decreased against resistant bacteria like E. faecalis, which can penetrate deeper dentinal tubules. Another reason for the lower percentage of bacterial reduction with diode laser irradiation could be justified by the findings of Borges et al.'s ${ }^{41}$ study. They reported that gram-positive bacteria such as $E$. faecalis need to be irradiated with additional-repeated modes for disruption of the bacterial cell wall. Although no effective bacterial reduction was determined and no attempts were made to find out main interaction between diode laser and E. faecalis, the main bactericidal mechanism of diode laser irradiation was based upon the photothermal effect, which stimulates the bacterial cell death by creating localized heating sides around the bacterial microenvironment. ${ }^{42}$

Essential oils that are rich in phenolic compounds in particular have the capabilities to change the permeability of cell membrane via diffusion into the phospholipids layer of the bacterial cell wall, thus affecting protein synthesis leading to cytoplasmic changes and blocking cellular functions. ${ }^{43,44}$

According to our results, the bactericidal effect of Origanum onites oil without diode laser irradiation as an intracanal irrigant agent on E. faecalis was inadequate (25.5\%). This situation may be explained with more than one action of mechanism. First, Origanum onites oil is highly vaporizable, so it may have lost its antibacterial effectiveness during incubation. Second, the primary tooth microstructure may complicate the

\begin{tabular}{|c|c|c|c|c|c|}
\hline Tukey's multiple comparisons test & Mean diff. & $95 \% \mathrm{Cl}$ of diff. & Significant & Summary & $P$ value \\
\hline Positive vs. $\mathrm{NaOCl}$ & 2.991 & 2.826 to 3.156 & Yes & $P<.0001$ & $<.0001$ \\
\hline Positive vs. diode laser & 0.9744 & 0.8093 to 1.139 & Yes & $P<.0001$ & $<.0001$ \\
\hline Positive vs. Origanum onites & 0.7784 & 0.6133 to 0.9435 & Yes & $P<.0001$ & $<.0001$ \\
\hline Positive vs. laser-Origanum onites & 2.816 & 2.651 to 2.981 & Yes & $P<.0001$ & $<.0001$ \\
\hline Negative vs. Origanum onites & -2.264 & -2.429 to -2.099 & Yes & $P<.0001$ & $<.0001$ \\
\hline Negative vs. diode laser-Origanum onites & -0.226 & -0.3911 to -0.06095 & Yes & $P<.005$ & .0022 \\
\hline $\mathrm{NaOCl}$ vs. diode laser & -2.017 & -2.182 to -1.852 & Yes & $P<.0001$ & $<.0001$ \\
\hline $\mathrm{NaOCl}$ vs. Origanum onites & -2.213 & -2.378 to -2.048 & Yes & $P<.0001$ & $<.0001$ \\
\hline $\mathrm{NaOCl}$ vs. diode laser-Origanum onites & -0.175 & -0.3401 to -0.009947 & Yes & $P<.05$ & .0317 \\
\hline Diode laser vs. Origanum onites & -0.196 & -0.3611 to -0.03095 & Yes & $P<.05$ & .0112 \\
\hline
\end{tabular}

Abbreviation: $\mathrm{NaOCl}$ : sodium hypochlorite. 
penetration of Origanum onites oil, which is viscous and may be unable to penetrate dentinal tubules, especially in the case of smear layer. In agreement with Man et al.'s ${ }^{45}$ study, the lower antibacterial effect of $\mathrm{OO}$ oil on $\mathrm{E}$. faecalis may be related to oil's aqueous form which leads to a decrease in its antibacterial activity. Resultantly, DMSO was preferred to decrease the hydrophobic viscous structure of essential oil and also to reduce its side effects in the present study. While DMSO decreases the side effects and viscous structure of $O O$ oil, it reduces the purity of essential oils. Therefore, in the present study, the $\mathrm{OO}$ oil was not used in its pure form, so that $O O$ oil alone was detected ineffective against to E. faecalis. Another important factor that affects the antibacterial activity is the thymol and carvacrol content of $\mathrm{OO}$ oil. Higher amounts of thymol exhibit stronger antibacterial activity. ${ }^{46}$ In a previous study by Başer, carvacrol was identified as the main component responsible for the biological activities of origanum species including Origanum onites. ${ }^{47}$ According to GC/MS analysis in the present study, carvacrol (78.4\%), $\gamma$-terpinene $(6.9 \%)$, and $p$-cymene $(4.1 \%)$ were detected as the major components of $O O$ oil. Therefore, the E. faecalis reduction capacity of Origanum onites oil in this study may be explained by its high carvacrol component. In contrast to Ok et al.'s ${ }^{20,21}$ studies, the reason for the differences with these studies may be caused by the lower percentage of thymol component $(0.2 \%)$ in $O O$ oil used our study and also the application area of the oregano essential oils. In $\mathrm{Ok}$ et al.'s $\mathrm{s}^{20,2}$ studies, oreganum extract solutions were found nontoxic and more effective against to $E$. faecalis than our results. Also thymol component was ranged between $1 \%$ and $1.25 \%$, and mature/permanent teeth were used in those studies.

Parallel to our results, the effectiveness of $\mathrm{NaOCl}$ was shown by Oliveira et al., ${ }^{48}$ who found that, as an endodontic irrigant, only $\mathrm{NaOCl}$ had the capacity to kill the entire bacterial population. Of the considered treatments, we similarly observed that $2.5 \% \mathrm{NaOCl}$ was the most effective endodontic irrigant for $E$. faecalis removal from primary root canals. However, this effective disinfection of $2.5 \% \mathrm{NaOCl}$ probably arose due to the larger instrumental size of the primary root canals. In agreement with Kumar et al.'s ${ }^{49}$ study, this larger preparation size of the root canals enables the dentinal tubules to be opened and removes the intratubular bacteria by allowing more effective penetration of $\mathrm{NaOCl}$.

In the current study, the antibacterial efficacy of diode laser $+\mathrm{OO}$ oil combination could be clarified by Al Shahrani et al.'s ${ }^{50}$ study, which claimed that the photonic energy of laser may activate and enhance irrigant agents by providing greater accessibility to unreachable parts of dentinal tubules. ${ }^{50}$ Furthermore, the increasing antibacterial effect of $\mathrm{OO}$ oil in the long-term (overnight) may be explained by the increased smear layer dissolution and dentinal tubule penetration of $\mathrm{OO}$ oil. In other words, diode laser may act as a synergistic factor when combined with $\mathrm{OO}$ oil, and thus diode laser may increase the antibacterial effect of $\mathrm{OO}$ oil.

Furthermore, in vivo experiments with larger sample size need to be tested for a better understanding of the main antibacterial mechanism of diode laser irradiation and Origanum onites oil.

Within the limitations of this study, we can conclude that the combined therapy of diode laser irradiation following $\mathrm{OO}$ oil application in primary root canal disinfection may be used as an ideal effective chemo-mechanical alternative to $\mathrm{NaOCl}$ irrigation, especially in larger apical sized primary teeth with physiological resorption. Also, antibiotic resistance due to longterm medicinal usage may be prevented using this method. Prior to using irrigant agents including herbal drugs or laser, the viscosity of an essential oil, complex morphological root-canal structure of primary teeth, smear layer, deep penetration to dentinal tubules, timing properties, and biocompatibility must be taken into consideration and the ideal agent must be selected. Further studies are required to provide a clinically valvable antibacterial treatment choice with minimal chair-time as an important point of children's treatment.

Ethics Committee Approval: Ethical committee approval was received from the Near East University (NEU / 2018 / 58-609).

Informed Consent: Written informed consent was obtained from patients before they participated in the study.

Peer-review: Externally peer-reviewed.

Author Contributions: Concept - A.I., S.S., S.Ç.; Design - A.I., S.S.; Supervision - S.Ç., K.H.C.B.; Resources - A.I., S.S., D.Y.H.; Materials - A.I., S.S., D.Y.H.; Data Collection and/or Processing - A.I., S.S., D.Y.H.; Analysis and/or Interpretation - A.I., S.S., D.Y.H., S.Ç., K.H.C.B.; Literature Search A.I., S.S.; Writing Manuscript - A.I., S.S., D.Y.H.; Critical Review - A.I., S.S., S.Ç., K.H.C.B.

Conflict of Interest: The authors have no conflicts of interest to declare.

Financial Disclosure: The authors declared that this study has received no financial support.

Source of the study: All experimental analysis was conducted in the Pediatric Dentistry Department and Microbiology Laboratory of Near East University.

\section{REFERENCES}

I. Gu LS, Kim JR, Ling J, Choi KK, Pahley DH, Tay FR. Review of contemporary irrigant agitation techniques and devices. J Endod. 2009;35(6):791-804. [CrossRef]

2. Sen BH, Safavi KE, Spangberg LSW. Antigungal effects of sodium hypochlorite and chlorhexidine in root canals. J Endod. 1999;25:235258. [CrossRef]

3. Rocas IN, Siqueira JF, Santos KR. Association of Enterecoccus faecalis with different forms of periradicular diseases. J Endod. 2004;30(5):315-320. [CrossRef]

4. Dederich DN, Zakariasen KL, Tulip J. Scanning electron microscopic analysis of canal wall dentin following neodymium-yttriumaluminum-garnet laser irradiation. J Endod. 1984;10(9):428-431. [CrossRef]

5. Miserendino LJ. The laser apicoectomy: Endodontic application of the $\mathrm{CO}_{2}$ laser for periapical surgery. Oral Surg Oral Med Oral Pathol. 1988;66(5):615-619. [CrossRef]

6. Cogulu D, Uzel A, Oncag O, Eronat C. PCR-based identification of selected pathogens associated with endodontic infections in deciduous and permanent teeth. Oral Surg Oral Med Oral Pathol Oral Endod. 2008;106(3):443-449. [CrossRef]

7. Sedgley CM, Lennan SL, Appelbe OK. Survival of Enterecoccus faecalis in root canals ex vivo. Int Endod J. 2005;38(I0):735-742. [CrossRef]

8. Porteiner I, Waltimo TMT, Haapasalo M. Enterecoccus faecalis-the root canal survivor and 'star' in post-treatment disease. Endod Top. 2003;6(I):135-159. [CrossRef] 
9. Sedgley CM, Molander A, Flannagan SE, et al. Virulance, phenotype and genotype characteristics of endodontic Enterecoccus spp. Oral Microbiol Immunol. 2005;20(I):10-19. [CrossRef]

10. Stuart CH, Schwartz SA, Beeson TJ, Owatz CB. Enterecoccus faecalis. Its role in root canal treatment failure and current concepts in retreatment. J Endod. 2006;32:93-98. [CrossRef]

II. Athanassiadis B, Abbott PV, Walsh LJ. The use of calcium hydroxide, antibiotics and biocides as antimicrobial medicaments in endodontics. Aust Dent J. 2007;52:64-82.

12. Ercan E, Ozekinci T, Atakul F, Gill K. Antibacterial activity of 2\% chlorhexidine and $5.25 \%$ sodium hypochlorite: An in vivo study. $J$ Endod. 2004;30:84-87. [CrossRef]

13. Chaugule VB, Panse AM, Gawali PN. Adverse reaction of sodium hypochlorite during endodontic treatment of primary teeth. Int $J$ Clin Pediatr Dent. 2015;8(2):153-I56. [CrossRef]

14. Bahrololoomi Z, Poursina F, Birang R, Foroughi E, Yousefshahi $\mathrm{H}$. The effect of Er:YAG laser on Enterecoccus faecalis bacterium in the pulpectomy of anterior primary teeth. J Lasers Med Sci. 2017;8(4):166-17I. [CrossRef]

15. Thomas S, Asokan S, John B, Priya G, Kumar S. Comparison of antimicrobial efficacy of diode laser, triphala, and sodium hypochlorite in primary root canals: A randomized controlled trial. Int J Clin Pediatr Dent. 2017;10(I):14-17. [CrossRef]

16. Forghani M, Afshari E, Parisay I, Garajian R. Effect of a passive sonic irrigation system on elimination of Enterecoccus faecalis from root canal system of primary teeth, using different concentrations of sodium hypochlorite: An in vitro evaluation. J Dent Res Dent Clin Dent Prospects. 2017;1I(3):177-182. [CrossRef]

17. Chinsembu KC. Plants and other natural products used in the management of oral infections and improvement of oral health. Acta Trop. 2016;154:6-18. [CrossRef]

18. Dadalioglu I, Evrendilek GA. Chemical compositions and antibacterial effects of essential oils of Turkish oregano (Origanum minutiflorum), Bay laurel (Laurus nobilis), Spanish lavender (Lavandula stoechas L.), and fennel (Foeniculum vulgare) on common foodborne pathogens. J Agric Food Chem. 2004;52:8255-8260. [CrossRef]

19. Baydar H, Sağdic O, Ozkan K, Karadoğan T. Antibacterial activity and composition of essential oils from Origanum, Thymbra and Satureja species with commercial importance in Turkey. Food Cont. 2004;15:169-172. [CrossRef]

20. Ok E, Adanir N, Ozturk T. Antibacterial and smear layer removal capability of oregano extract solution. Eur J Dent. 2015;9(I):020-024. [CrossRef]

21. Ok E, Adanir N, Hakkı S. Comparison of cytotoxicity of various concentrations origanum extract solution with $2 \%$ chlorhexidine gluconate and 5.25\% sodium hypochlorite. Eur J Dent. 2015;9(I):6-I0.

22. Ahirwar P, Shashikiran ND, Sundarraj RK, Singhla S, Thakur RA, Maran S. A clinical trial comparing antimicrobial efficacy of "essential oil of Ocimum sanctum" with triple antibiotic paste as an intracanal medicament in primary molars. $J$ Indian Soc Pedod Prev Dent. 2018;36(2):191-197. [CrossRef]

23. Chandwani M, Mittal R, Chandak S, Pimpale J. Effectiveness of Morinda citrifolia juice as an intracanal irrigant in deciduous molars: An in vivo study. Dent Res J. 2017;14(4):246-25I. [CrossRef]

24. Balto H, Salama F, Al-Mofareh S, Al-Yahya F. Evaluation of different irrigating solutions on smear layer removal of primary root dentin. J Contemp Dent Pract. 2015;16(3):187-191. [CrossRef]

25. Govaris A, Solomakos N, Pexara A, Chatzopoulou PS. The antimicrobial effect of oregano essential oil, nisin and their combination against Salmonella enteritidis in minced sheep meat during refrigerated storage. Int J Food Microbiol. 2010;137:175-180. [CrossRef]

26. Davis PH, Mill RR, Tan K. Flora of Turkey and the East Aegean Islands. Vol. I0. Edinburgh, UK: University Press, 1988.
27. Guner A, Ozhatay N, Ekim T, et al. Flora of Turkey and the East Aegean Islands. Vol. II. Edinburgh, UK: University Press, 2000.

28. De Falco E, Mancini E, Roscigno G, et al. Chemical composition and biological activity of essential oils of Origanum vulgare L. subsp. vulgare L. under different growth conditions. Molecules. 2013;18:14948-14960. [CrossRef]

29. McLafferty FW, Stauffer DB. 1989. The Wiley/NBS Registry of Mass Spectral Data. New York: John Wiley and Sons.

30. Linstrom PJ, Mallard WG (eds.). NIST Chemistry WebBook. NIST Standard Reference Database Number 69. Gaithersburg, MD: National Institute of Standards and Technology.

31. Joulain D, Koenig WA. The Atlas of Spectra Data of Sesquiterpene Hydrocarbons. Hamburg: EB-Verlag, 1998.

32. ESO 2000. The Complete Database of Essential Oils. Netherlands: Boelens Aroma Chemical Information Service, 1999.

33. Dickers $B$, Lamard $L$, Peremans $A$, et al. Temperature rise during photo-activated disinfection of root canals. Lasers Med Sci. 2009;24(I):81-85. [CrossRef]

34. Kuvvetli SS, Sandalli N, Topcuoglu N, Kulekci G. Antibacterial efficacy of diode and Er:YAG laser irradiation in experimentally contaminated primary molar root canals. J Clin Pediatr Dent. 2009;34(I):43-48. [CrossRef]

35. Schoop U, Kluger W, Moritz A, et al. Bactericidal effect of different laser systems in the deep layers of dentin. Lasers Surg Med. 2004;35(2):III-II6. [CrossRef]

36. Nammou S, Kowaly K, Powell GL, et al. External temperature during KTP-Nd:YAG laser irradiation in root canals: $A n$ in vitro study. Lasers Med Sci. 2004;19(I):27-32. [CrossRef]

37. Moritz A, Gutknecht N, Schoop U, et al. Irradiation of infected root canals with a diode laser in vivo: Results of microbiological examinations. Lasers Surg Med. 1997;21(3):221-226. [CrossRef]

38. Dai SS, Xiao G, Zhang $L$, et al. The cleaning effect of diode laser on smear layer on root canals of primary teeth. J Oral Sci Res. 20l6;32(7):742-745.

39. Masuda $Y$, Sakagami $H$, Horiike $M$, Kadokura $H$, et al. Photodynamic therapy with pyoktanin blue and diode laser for elimination of Enterococcus faecalis. in vivo. 2018;32(4):707-712. [CrossRef]

40. Roshdy NN, Kataia EM, Helmy NA. Assessment of antibacterial activity of $2.5 \% \mathrm{NaOCl}$, chitosan nano-particles against Enterecoccus faecalis contaminating root canals with and without diode laser irradiation: An in vitro study. Acta Odon Scandi. 2018. DOI: 10.1080/00016357.2018.1498125.

4l. Borges CC, Estrela C, Lopes FC, et al. Effect of different diode laser wavelengths on root dentin decontamination infected with Enterecoccus faecalis. J Photochem Photobiol B. 2017;176:1-8. [CrossRef]

42. Pirnat S, Lukac M, Ihan A. Study of the direct bactericidal effect of $\mathrm{Nd}: Y A G$ and diode laser parameters used in endodontics on pigmented and nonpigmented bacteria. Lasers Med Sci. 2011;26:755761. [CrossRef]

43. De Souza EL, de Barros JC, de Oliveira CEV, et al. Influence of Origanum vulgare L. essential oil on enterotoxin production, membrane permeability and surface characteristics of Staphylococcus aureus. Int J Food Microbiol. 2010;137:308-3II. [CrossRef]

44. Sakkas H, Gousia P, Economou V, et al. In vitro antimicrobial activity of five essential oils on multidrug resistant gram-negative clinical isolates. J Intercult Ethnopharmacol. 2016;5(3):212-218. [CrossRef]

45. Man A, Santacroce L, Jacob R, et al. Antimicrobial activity of six essential oils against a group of human pathogens: $A$ comparative study. Pathogens. 2019;8(I):El5. [CrossRef]

46. Mohtashami S, Rowshan $V$, Tabrizi $L$, et al. Summer savory (Satureja hortensis L.) essential oil constituent oscillation at 
different storage conditions. Ind Crops Prod. 20|8;|ll:226-231. [CrossRef]

47. Başer $\mathrm{KH}$. Biological and pharmacological activities of carvacrol and carvacrol bearing essential oils. Curr Pharm Design. 2008;14:3106-3119. [CrossRef]

48. Oliveira JR, de Jesus Viegas D, Martins APR, et al. Thymus vulgaris L. extract has antimicrobial and anri-inflammatory effects in the absence of cytotoxicity and genotoxicity. Arch Oral Biol. 2017;82:27I-279. [CrossRef]
49. Kumar T, Dhillon JS, Ghill GS, et al. An in vitro comparison of the antimicrobial efficacy of positive pressure and negative pressure irrigation techniques in root canals infected with Enterecoccus faecalis. J Conserv Dent. 2018;21(4):438-442. [CrossRef]

50. Al Shahrani M, Divito E, Hughes $C V$, et al. Enhanced removal of Enterococcus faecalis biofilms in the root canal using sodium hypochlorite plus photon-induced photoacoustic streaming: An in vitro study. Photomed Laser Surg. 2014;32(5):260-266. [CrossRef] 